\title{
Volume and antimicrobial activity of secretions of the uropygial gland are correlated with malaria infection in house sparrows
}

\author{
Sergio Magallanes ${ }^{1}$, Anders Pape Møller², Luz García-Longoria', Florentino de Lope ${ }^{1}$ and Alfonso Marzal ${ }^{1 *}$
}

\begin{abstract}
Background: Animals have developed a wide range of defensive mechanisms against parasites to reduce the likelihood of infection and its negative fitness costs. The uropygial gland is an exocrine gland that produces antimicrobial and antifungal secretions with properties used as a defensive barrier on skin and plumage. This secretion has been proposed to affect the interaction between avian hosts and their ectoparasites. Because uropygial secretions may constitute a defense mechanism against ectoparasites, this may result in a reduction in prevalence of blood parasites that are transmitted by ectoparasitic vectors. Furthermore, other studies pointed out that vectors could be attracted by uropygial secretions and hence increase the probability of becoming infected. Here we explored the relationship between uropygial gland size, antimicrobial activity of uropygial secretions and malaria infection in house sparrows Passer domesticus.
\end{abstract}

Methods: A nested-PCR was used to identify blood parasites infection. Flow cytometry detecting absolute cell counting assessed antimicrobial activity of the uropygial gland secretion

Results: Uninfected house sparrows had larger uropygial glands and higher antimicrobial activity in uropygial secretions than infected individuals. We found a positive association between uropygial gland size and scaled body mass index, but only in uninfected sparrows. Female house sparrows had larger uropygial glands and higher antimicrobial activity of gland secretions than males.

Conclusion: These findings suggest that uropygial gland secretions may play an important role as a defensive mechanism against malaria infection.

Keywords: Antimicrobial activity, Flow cytometry, Haemosporidian parasites, Passer domesticus, Preen gland

\section{Background}

Parasites are ubiquitous and the most abundant organisms on Earth $[1,2]$. They cause harmful effects on their hosts and negatively influence different host fitness components, such as growth [3], survival [4], fecundity [5] and reproductive output [6,7]. Because of these effects exerted by parasites, animal hosts have developed a wide range of defensive mechanisms in order to reduce the likelihood of infection and/or its negative effects $[8,9]$.

\footnotetext{
* Correspondence: amarzal@unex.es

${ }^{1}$ Departamento de Anatomía Biología Celular y Zoología, Universidad de Extremadura, Avda. de Elvas s/n, E-06006 Badajoz, Spain

Full list of author information is available at the end of the article
}

These mechanisms include natural resistance to infection such as physical barriers to invading pathogens or high-density lipoproteins in human serum destroying trypanosomes $[8,10]$, nonspecific immune responses such as generation of oxidative products by the phagocytes to destroy microbes [11], specific immune responses such as the production of a variety of antibodies that bind to specific pathogens [12], or behaviours aiming to control exposure to parasites [13, 14].

Avian malaria and related haemosporidian parasites are among the most pathogenic species of poultry and wild birds [15]. These widespread organisms cause detrimental effects on life history of their avian hosts by reducing 
survival [16, 17], reproductive success $[7,18,19]$ and body condition [20, 21]. They show a complex life-cycle [15], in which the presence of a vector (biting midges, black flies, louse flies and a large number of mosquito species) is needed for transmission of the disease [15, 22].

The uropygial gland (also called preen gland) is an exocrine gland of birds secreting waxes with antimicrobial and antifungal properties that is smeared on the plumage during preening and hence acting as defensive barrier of skin and plumage [23-27]. This secretion has been proposed to play an important role in host-parasite relationships because it may affect the interaction between birds and their vectors [28, 29]. However, the possible role of the uropygial gland in protection against haemosporidian parasites still remains unclear.

Uropygial secretions may prevent birds from acquiring blood parasite infection. Mammalophilic and ornithophilic mosquitoes and other ectoparasites act as disease vectors that rely on different cues to locate their potential blood hosts. Host finding by vectors is largely driven by visual stimuli [30], exuded heat resulting from metabolic activity of hosts [31] and odorant and volatile organic chemicals produced by skin and plumage bacteria that are emitted by individual hosts [32-34]. Therefore, the antimicrobial activity of the uropygial secretion from birds can decrease feather and skin microbiota and hence reduce the emission of chemical cues used by haemosporidian vectors. This should minimize the likelihood of being infected with these blood parasites. In addition, compounds isolated from secretions of the uropygial gland have an insecticidal effect [35] and can act as ectoparasite repellents [36]. Therefore, these secretions may also decrease the probabilities of haemosporidian infection.

Alternatively, antiparasite defences may negatively affect hosts when such defences become attractants for parasites or vectors. Following this idea, several studies have indicated that uropygial secretions may be used by haemosporidian vectors to locate potential hosts and infect them. For example, Lowther \& Wood reported that some species of black flies were strongly attracted to uropygial gland extracts from common loon (Gavia immer) [37]. Similarly, Fallis \& Smith pinpointed the uropygial gland as one of the main sources of black fly attraction to common loons [28]. Moreover, Bennett et al. successfully used ether extract of the uropygial gland of the common loon to attract simulids [38]. More recently, Russell \& Hunter showed that traps baited with uropygial secretion from American crows Corvus brachyrhynchos captured more Culex mosquitoes, one of the main avian malaria vectors [15], than unbaited blank control traps [29].

Here we investigate these two hypotheses on the role of uropygial gland secretions on haemosporidian infections in the house sparrow Passer domesticus, one of the most ubiquitous hosts for avian malaria [39]. First, we analyse the relationship between haemosporidian infection and the size of the uropygial gland, a reliable measure of the volume of produced secretion [40]. If the properties of uropygial secretions can minimize the attraction of vectors to birds, then we expect a lower prevalence of haemosporidian infection in individual birds with larger uropygial glands. In contrast, if haemosporidian vectors are attracted to the uropygial secretion, then we should expect that sparrows with larger uropygial glands were more prone to infection with haemosporidians than birds with smaller glands. Secondly, we explore the relationship between antimicrobial capacity of secretions from the preen gland and blood parasite infection. If haemosporidian infection can be mediated by odour stimuli produced by skin and plumage bacteria attracting insect vectors, we should expect that sparrows with higher antibacterial activity of their gland secretions would have a lower probability of being infected with these blood parasites.

\section{Methods}

\section{Study sites and sample collection}

The study was carried out in a rural $\left(38^{\circ} 39^{\prime} \mathrm{N}, 7^{\circ} 13^{\prime} \mathrm{W}\right)$ and an urban population $\left(38^{\circ} 53^{\prime} \mathrm{N}, 7^{\circ} 00^{\prime} \mathrm{W}\right)$ near Badajoz, southwest Spain between November - December 2014. We captured 222 adult house sparrows (55 sparrows in one urban site, 167 sparrows in one rural site) in five days during the same week with mist-nets and recorded their body mass with a digital balance to the nearest $0.1 \mathrm{~g}$. We measured tarsus length with a digital calliper to the nearest $0.01 \mathrm{~mm}$. We used body mass and tarsus length to calculate scaled body mass index [41], which is a reliable estimate of animal physical condition [42]. Each individual was individually identified with a numbered metal ring and sexed according to Svensson et al. [43]. One microcapillary of blood $(70 \mu \mathrm{l})$ was obtained from the brachial vein of each individual and stored in $500 \mu \mathrm{l}$ of SET buffer $(0.15 \mathrm{M} \mathrm{NaCl}, 0.05$ Tris, 0.001 M EDTA, pH 8.0) until DNA extraction.

\section{Molecular detection of blood parasite infections}

Haemosporidian parasites (Plasmodium spp. and Haemoproteus spp.) were detected from blood samples using molecular methods [44, 45]. DNA from the avian blood samples was extracted in the laboratory using a standard chloroform/isoamylalcohol method [46]. Diluted genomic DNA (25 ng/ $\mu \mathrm{l})$ was used as a template in a polymerase chain reaction (PCR) assay for detection of the parasites using nested-PCR protocols described by Waldenström et al. [45]. The amplification was evaluated by running $2.5 \mathrm{ml}$ of the final PCR on a $2 \%$ agarose gel. All PCR experiments contained one positive control and 
one negative control for every eight samples. In the very few cases of negative controls showing signs of amplification (never more than faint bands in agarose gels), the whole PCR-batch was run again to make sure that all positives were true.

\section{Volume of the uropygial gland secretion}

We recorded length, height and width of the uropygial gland with a digital calliper with a precision of $0.01 \mathrm{~mm}$. Uropygial gland volume was estimated as the product of length, height and width [47], which is positively related to the volume of uropygial gland secretions $[26,40,48]$. Because the uropygial gland is a soft tissue $[26,48]$, we measured the three dimensions of uropygial gland three times to calculate repeatability $[26,49,50]$.

We also extracted all the secretion available in the uropygial papilla immediately after capture of 44 individuals from the same location, following the extraction protocol described by Martín-Vivaldi et al. [48]. Briefly, we first washed the uropygial gland and surrounding skin with a cotton swab soaked in ethanol to reduce the risk of contamination of the secretion. After evaporation of the alcohol, the papilla was softly pressed with a finger to expel the secretion and transfer it into a microcapillary tube until the papilla was empty. Immediately after extraction we estimated the volume of the secretion in the filled capillary tube with a digital calliper with an accuracy of $0.01 \mathrm{~mm}$. The extracted secretion was transferred to a sterile Eppendorf vial and kept at about $4{ }^{\circ} \mathrm{C}$ in a portable icebox, and stored in the laboratory at $-20^{\circ}$ $\mathrm{C}$ during the next $4 \mathrm{~h}$ until analyses of anti-microbial activity.

\section{Bacterial growth and antimicrobial activity of uropygial gland secretions}

The pellet of Staphylococcus epidermidis (ATCC ${ }^{\circ}$ CRM - $12228^{\mathrm{mm}}$ ) was re-suspended in $6 \mathrm{ml}$ of Luria - Bertani (LB) media to an OD $0.4-0.6$ and incubated at $37{ }^{\circ} \mathrm{C}$ with shaking for $24 \mathrm{~h}$. The bacterial suspension was then centrifuged in a Microfuge (Beckman Coulter) for $6 \mathrm{~min}$ at $2000 \mathrm{~g}$. After discarding the supernatant, the bacterial pellet was re-suspended carefully in $20 \mathrm{ml} \mathrm{LB}$ solution. A total of $200 \mu \mathrm{l}$ per well of bacterial suspension were then dispensed in a 96-well plate. Uropygial secretions were diluted 1:1 in dimethylsulfoxide (DMSO); $1 \mu \mathrm{l}$ of the uropygial secretion diluted with DMSO was added to the bacteria culture in each well. Four wells on a 96well plate with bacteria solution were not added with uropygial secretions but with $1 \mu \mathrm{l}$ of DMSO, as they were used as controls of bacterial growth. After culture incubation for bacterial growth at $37^{\circ} \mathrm{C}$ for $24 \mathrm{~h}$, the 96 well plate was covered and centrifuged in a plate centrifuge (Selecta, Spain) for $5 \mathrm{~min}$ at $2000 \mathrm{~g}$ and the pellet were re-suspended in $200 \mu \mathrm{l}$ of PBS at a final concentration of $0.6 \mu \mathrm{g} / \mathrm{ml}$. Samples were then incubated at $37^{\circ} \mathrm{C}$ for $30 \mathrm{~min}$ in the dark with shaking. Flow cytometry detecting absolute cell counting assessed antimicrobial activity of the uropygial gland against S. epidermidis secretion. This technique is a rapid, accurate and highly reproducible methodology used in clinical microbiology to monitor antimicrobial activity [51]. A total of $50 \mu \mathrm{l}$ of the cell suspension from each well was acquired using a MACSQuant $^{\circ} \mathrm{X}$ (Miltenyi Biotec) flow cytometer that allows absolute cell counting. Antimicrobial activity was evaluated by comparison of cell counting (bacterial growth) in wells with presence or absence (controls) of uropygial secretion.

\section{Statistical procedures}

Repeatability of uropygial gland measurements was calculated following the approximate Gaussian LMM using REML estimation $\left(\mathrm{R}_{\mathrm{M} \text { (REML) }}\right)$ described by Nakagawa \& Schielzeth [52]. We performed Shapiro-Wilk test for normality of distribution of data and used general linear models (GLM) to investigate the relationship between sex, locality (i.e. environmental variation), scaled body mass index, infection status (uninfected or infected) and the two-way interactions between sex and scaled body mass index, between infection status and scaled body mass index, and between infection and locality, on the uropygial gland volume. We used Pearson correlation test to determine the strength of association between uropygial gland volume and scaled body mass index regarding to sex and infection. We also used a GLM to evaluate the correlation between sex, uropygial gland volume, scaled body mass index and infection status (uninfected or infected) on the antimicrobial activity of the uropygial secretion. All analyses were performed using $R$ version 3.2.2 [53] and JMP [54].

\section{Ethics statement}

Methods were evaluated and approved by Institutional Commission of Bioethics of University of Extremadura (CBUE 49/2011). All the experiments comply with the current laws of Spain, where the experiments were performed.

\section{Results}

We analysed 222 blood samples from house sparrows in search of blood parasites. A total of $74 \%$ (165 individuals) were uninfected and $26 \%$ (57) were infected with blood parasites (13.5\% of sparrows infected in the rural location, $49.1 \%$ of sparrows infected in the urban location).

The uropygial gland volume and the antimicrobial activity of the uropygial secretion showed a normal distribution (Shapiro-Wilk normality test; Uropygial gland volume: $N=222, \quad W=0.923, \quad P>0.001$; antimicrobial 
activity: $N=44, W=0.943, P=0.030)$. We found a high repeatability between measurements of length, width and height of uropygial gland (all $R>0.81$ and $P<0.05$ ).

Prevalence of haemosporidian parasites, sex and locality explained significant variation in size of the uropygial gland. In contrast, scaled body mass index was not significantly correlated with size of the uropygial gland (Table 1). Specifically, the volume of the uropygial gland was larger in uninfected than in infected house sparrows [mean uropygial gland volume (standard deviation, SD): uninfected $=171.84 \mathrm{~mm}^{3}$ (43.22); infected $=161.03 \mathrm{~mm}^{3}$ (34.33)]. Furthermore, the volume of the uropygial gland differed between the sexes, with females having larger glands than males [mean uropygial gland volume (SD): females = $171.57 \mathrm{~mm}^{3}$ (40.01); males $=167.36 \mathrm{~mm}^{3}$ (42.26)]. Moreover, the volume of the uropygial gland differed significantly among localities, with house sparrows living in an urban site having larger uropygial glands than sparrows in a rural site [(mean uropygial gland volume $(\mathrm{SD})$ : urban sparrows $=184.75 \mathrm{~mm}^{3} \quad(45.28) ; \quad$ rural sparrows $=$ $163.90 \mathrm{~mm}^{3}$ (38.70)].

The relationship between the volume of the uropygial gland and scaled body mass index varied with haemosporidian infection (Table 1; Fig. 1). Specifically, there was a positive relationship between gland size and scaled body mass index in uninfected house sparrows $(r=0.392 ; P<0.001)$, while there was no significant relationship in individuals infected with haemosporidians $(r=-0.077 ; P=0.568)$. We also found a positive relationship between gland size and scaled body mass index in both males $(r=0.271 ; P=0.002)$ and females $(r=0.349 ; P=0.001)$.

In a second GLM we examined if antimicrobial activity of the uropygial secretion varied with sex, haemosporidian infection, scaled body mass index and uropygial gland volume. The estimate of antimicrobial activity of the uropygial gland varied with haemosporidian infection and sex (Table 2). Specifically, antimicrobial activity

Table 1 Factors explaining the variation in volume of the uropygial gland in house sparrows. Scaled body mass index, haemosporidian infection, sex, locality and the two-way interactions between sex and scaled body mass index, between infection status and scaled body mass index and between infection and locality were included in the analysis as predictor variables. Sample size was 222 individuals

\begin{tabular}{lclrl}
\hline Independent variable & Square-sum III & DF & \multicolumn{1}{l}{$F$} & $P$ \\
\hline Scaled body mass index & 4695.89 & 1 & 0.190 & 0.7176 \\
Infection & 3787.71 & 1 & 4.082 & 0.046 \\
Sex & 5574.75 & 1 & 4.122 & 0.036 \\
Locality & 14282.25 & 1 & 10.464 & $<0.001$ \\
Sex $\times$ Scaled body mass & 5061.31 & 1 & 4.084 & 0.045 \\
Infection $\times$ Scaled body mass & 4695.89 & 1 & 4.354 & 0.027 \\
Infection $\times$ Locality & 1153.53 & 1 & 0.845 & 0.359 \\
\hline
\end{tabular}

of uropygial secretion was significantly higher in uninfected than in infected birds [mean antimicrobial activity $(\mathrm{SD})$ : infected $=11.08$ (9.76); uninfected $=20.39(15.81)$ ] Finally, uropygial gland secretions from female sparrows had a slightly higher antimicrobial activity than secretions from male sparrows, although non-significantly so [mean antimicrobial activity (SD): females $=20.79$ (16.66); males $=16.18$ (13.73)].

\section{Discussion}

Uropygial secretions have been hypothesized to play an important role in the interaction between birds and haemosporidian parasites because it can affect the interaction between hosts and their vectors. Although the results from some studies do not support a potential role of avian uropygial gland secretions in attracting haemosporidian vectors [55], other studies have indicated that preen oil secretions may constitute a defence mechanism against ectoparasites and thus avoidance of blood parasite infections [56]. In contrast, other studies suggest that haemosporidian vectors may be attracted by uropygial secretions $[28,29]$. Here we explored the relationship between uropygial gland size, antimicrobial activity of uropygial secretions and malaria infection in house sparrows. The main findings of this study were that (i) uninfected house sparrows had larger uropygial glands and higher antimicrobial activity in uropygial secretions than infected house sparrows; and (ii) female house sparrows had larger uropygial glands and higher antimicrobial activity than males. We briefly discuss these results.

More than 200 blood samples from house sparrows were analysed in search of blood parasites. A total of $26 \%$ of house sparrows were infected with haemosporidian parasites. Similar haemosporidian prevalence during winter has been found in previous studies of house sparrows from the same area [57].

Uninfected house sparrows had larger uropygial glands than infected house sparrows, suggesting that the uropygial gland and its secretions may constitute defences against ectoparasites, and thus against haemosporidian infection. Thus, González [58] have recently shown that ectoparasite richness and ectoparasite burden is negatively related to the mass of the uropygial gland in rock ptarmigan (Lagopus muta). Moreover, other studies have shown that individuals with larger glands, and, therefore, able to produce more uropygial secretions, have lower prevalence of ectoparasites $[48,59]$. We propose different mechanisms that may explain this protection by preen secretions against ectoparasites. First, uropygial secretions may act as a physical barrier against vectors by reducing their mobility on the bird's plumage or skin [56]. Secondly, uropygial secretions could act as an insecticide and kill ectoparasites by covering the surface of the parasite or blocking their spiracles [35]. Finally, 


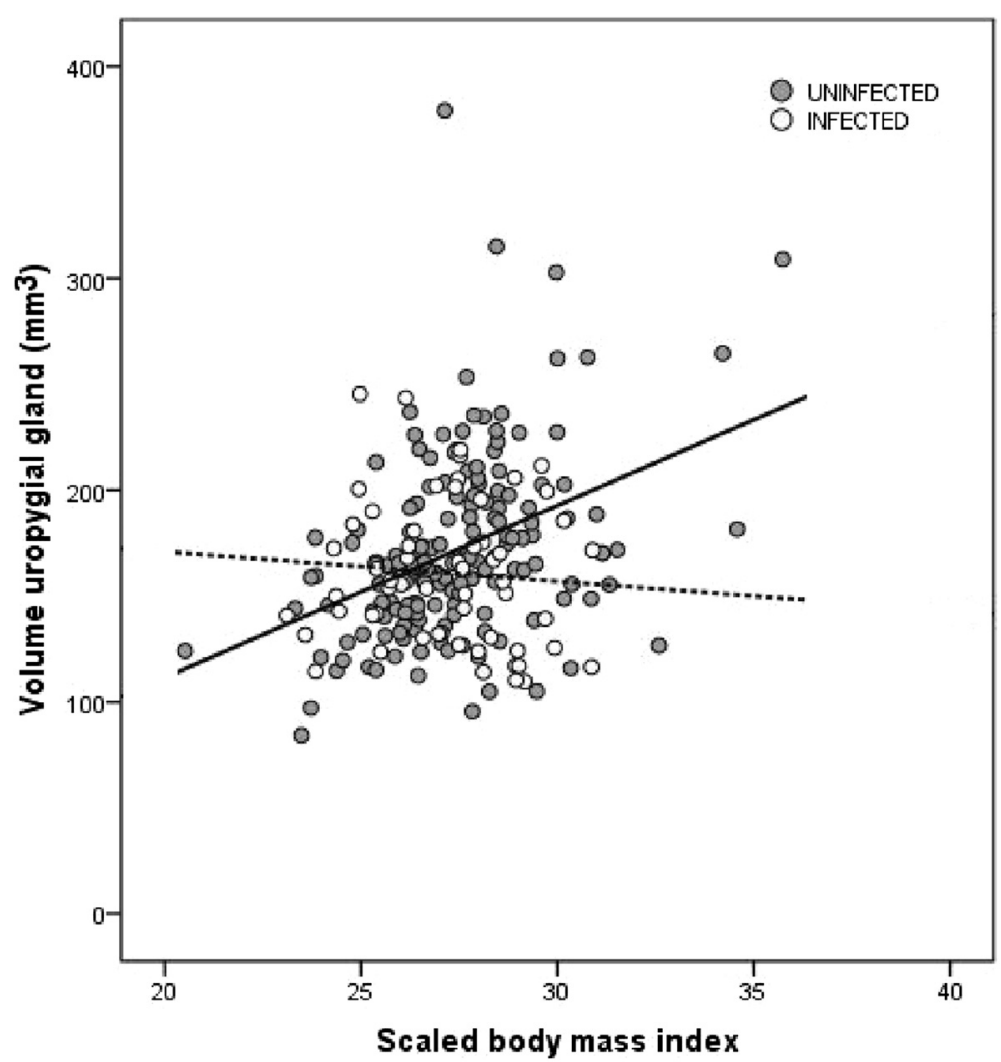

Fig. 1 Scatterplot showing the relationship between the volume of the uropygial gland $\left(\mathrm{mm}^{3}\right)$ and scaled body mass index in haemosporidian infected (white circles, dotted line, $N=57$ ) and uninfected house sparrows (grey circles, solid line, $N=165$ )

preen secretions may be associated with noxious or repellent odours that possibly affect ectoparasites, as has been shown in some species of birds [60]. We also found a positive and significant relationship between gland size and scaled body mass index in uninfected house sparrows, while the volume of the uropygial gland was not significantly related to scaled body mass index among malaria infected sparrows. These findings suggest that development of the uropygial gland is costly and may impair energetic demands [61,62]. Thus, only individuals in prime condition (uninfected sparrows) should be

Table 2 Factors explaining the variation in antimicrobial activity of the uropygial gland in house sparrows. Scaled body mass index, haemosporidian infection, sex and uropygial gland volume were included in the analysis as predictor variables. Sample size was 44 individuals

\begin{tabular}{lclll}
\hline Independent variable & Square-sum III & DF & $F$ & $P$ \\
\hline Scaled body mass index & 1.38 & 1 & 2.011 & 0.1756 \\
Infection & -2.43 & 1 & 5.850 & 0.0196 \\
Sex & 1.75 & 1 & 2.947 & 0.0872 \\
Gland volume & -5.19 & 1 & 0.297 & 0.4968 \\
\hline
\end{tabular}

able to invest in anti-microbial defence without compromising other fitness-related traits.

The antimicrobial and anti-fungal properties of uropygial secretions may benefit birds by avoiding haemosporidian infection. Consistently, we showed that the antimicrobial activity of the uropygial gland in uninfected house sparrows was higher than that of gland secretions from infected birds. As far as we are aware, this is the first study showing a relationship between antimicrobial activity of uropygial secretions and haemosporidian infection. We hypothesize that this relationship may be mediated by a decrease in olfactory stimuli for insect vectors caused by preen secretions. Accordingly, it has been shown that the odours emanating from gland secretions and the microflora of the skin may play an important role in attraction of malaria vectors in humans [63-65]. Birds harbour a great diversity of microbes on feathers and skin, which may be involved in the production of chemical attractants for haemosporidian vectors like Culex spp. and simulids $[28,37,66]$. Hence, the elimination of bacteria and fungi from feathers and skin by uropygial secretions could decrease vector attraction and thus minimize the likelihood of becoming infected with haemosporidians. Following this idea, uropygial secretions may affect different strains 
of parasitic bacteria and fungi in different ways. For example, it has been shown that volatile compounds (saturated fatty acids, benzaldehyde and phenol, among others) from uropygial gland secretions provide strong antimicrobial action in birds [67]. Similarly, Jacob et al. showed that uropygial secretions from birds of the order Pelecaniformes had an antagonist effect on fungal dermatophytes and an antibacterial effect on Gram-positive bacteria [68]. Moreover, Law-Brown experimentally showed activity of uropygial secretions against 13 pathogenic bacterial strains from the genera Salmonella, Staphylococcus and Streptococcus [69]. Additionally, it has been proposed that pathogenic bacteria and fungi may be controlled through the synthesis of bacteriocins and other antimicrobial actions of certain symbiotic bacteria that live in the preen gland [23-25, 70].

Female house sparrows have larger uropygial glands than male sparrows. In agreement with our results, previous studies of birds have shown that females have larger glands than males [40, 48, 59]. Moreover, the antimicrobial activity of preen secretions from female sparrows was slightly higher than that of males. Bacteria and other pathogens in the nest are known to be one of the main factors affecting egg survival and hatching success [71-73]. Because in many species of birds females spend more time in nests during incubation and nestling periods than males [74, 75], larger uropygial glands and/or higher antibacterial capacities may lead to a fitness advantage in terms of higher hatching success [76]. Alternatively, several studies have shown that females are more infected with haemosporidian parasites than males $[77,78]$, suggesting a female bias in exposure to the vectors [79]. Because time spent in the nest can increase the risks of becoming infected with haemosporidian parasites [15], larger uropygial glands and higher antimicrobial activity may provide females with a higher protection against haemosporidian vectors.

Birds are expected to modify their investment in defensive traits (uropygial gland) in response to differences in exposure to microorganisms [80]. Animals living in cities are exposed to more pathogenic diseases than their rural counterparts [81, 82]. In agreement with these expectations, we found a significant difference in size of uropygial glands between populations. However, our results rely on only one single comparison, and hence, we need more replicates of uropygial gland sizes from other urban and rural populations of house sparrows in order to draw firm conclusions.

\section{Conclusion}

In conclusion, the size of the uropygial gland and the antimicrobial activity of its secretions varied with haemosporidian infection and sex in house sparrows. These findings suggest that uropygial glands may be involved in defensive mechanisms against malarial infections under natural conditions. Further experimental studies could help improve our understanding of this birdparasite interaction. They may also help to test if uropygial secretions may have properties that reduce or eliminate the risk of malarial infection.

\section{Competing interests}

The authors declare that they have no competing interests.

\section{Authors' contributions}

SM, APM and AM designed the study. All authors processed and analyzed the data. SM, APM and AM wrote the manuscript. All authors read and approved the final version of the manuscript.

\section{Acknowledgments}

We are grateful to technical and human support provided by the Facility of Bioscience Applied Techniques of SAIUEx (financed by UEX, Junta de

Extremadura, MICINN, FEDER and FSE). This study was funded by research projects of the Spanish Ministry of Economy and Competitiveness (CGL2012-36665) and the Junta de Extremadura (GRU15117). SM was supported by a PhD grant from the Ministry of Economy and Competition of Spain. All the experiments comply with the current laws of Spain, where the experiments were performed.

\section{Author details}

${ }^{1}$ Departamento de Anatomía Biología Celular y Zoología, Universidad de Extremadura, Avda. de Elvas s/n, E-06006 Badajoz, Spain. ${ }^{2}$ Laboratoire d'Ecologie, Systématique et Evolution, CNRS UMR 8079, Université Paris-Sud, Bâtiment 362, F-91405 Orsay Cedex, France.

Received: 19 January 2016 Accepted: 14 April 2016

Published online: 25 April 2016

\section{References}

1. Poulin R, Morand S. Parasite biodiversity. Washington DC: Smithsonian Institution Books; 2004

2. Dobson A, Lafferty KD, Kuris AM, Hechinger RF, Jetz W. Colloquium paper: Homage to Linnaeus: How many parasites? How many hosts? Proc Natl Acad Sci. 2008;105:11482-9.

3. Kelehear C, Spratt DM, Dubey S, Brown GP, Shine R. Using combined morphological, allometric and molecular approaches to identify species of the genus Raillietiella (Pentastomida). PLoS One. 2011;6:e24936.

4. Martínez de la Puente J, Merino S, Tomás G, Moreno J, Morales J, Lobato E, et al. The blood parasite Haemoproteus reduces survival in a wild bird: A medication experiment. Biol Lett. 2010;6:663-5.

5. Abbate J, Kada S, Lion S. Beyond mortality: Sterility as a neglected component of parasite virulence. PLoS Pathog. 2015;11:e1005229.

6. Merino S, Moreno J, Jose J, Arriero E. Are avian blood parasites pathogenic in the wild? A medication experiment in blue tits (Parus caeruleus). Proc R Soc. 2000;9:2507-10

7. Marzal A, de Lope F, Navarro C, Møller AP. Malarial parasites decrease reproductive success: an experimental study in a passerine bird. Oecologia. 2005;142:541-5

8. Wakelin D. Immunity to parasites: how parasitic infections are controlled. Cambridge: Cambridge University Press; 1996.

9. Poulin R. Evolutionary ecology of parasites. London: Chapman \& Hall; 1998.

10. Raper J, Portela MPM, Lugli E, Frevert U, Tomlinson S. Trypanosome lytic factors: novel mediators of human innate immunity. Curr Opin Microbiol. 2001;4:402-8

11. Nordenfelt $P$, Tapper $H$. Phagosome dynamics during phagocytosis by neutrophils. J Leukoc Biol. 2011;90:271-84.

12. Parham P. The Immune System. New York: Garland Science; 2014.

13. Moore J. Parasites and the behavior of animals, vol. 88. Oxford: Oxford University Press; 2002.

14. Gray B, Jacobs AC, Mora AB, Zuk M. Antiparasite behavior. Curr Biol. 2012;22:R255-R7.

15. Valkiūnas G. Avian malaria parasites and other Haemosporidia. Boca Raton. Florida: CRC Press; 2005. 
16. Asghar M, Hasselquist D, Hansson B, Zehtindjiev P, Westerdahl H, Bensch S Hidden costs of infection: chronic malaria accelerates telomere degradation and senescence in wild birds. Science. 2015;347:436-8.

17. Marzal A, Balbontín J, Reviriego M, García-Longoria L, Relinque C, Hermosell IG, et al. A longitudinal study of age-related changes in Haemoproteus infection in a passerine bird. Oikos. in press. 2015.

18. Asghar M, Hasselquist D, Bensch S. Are chronic avian haemosporidian infections costly in wild birds? J Avian Biol. 2011;42:530-7.

19. Tomás G, Merino S, Moreno J, Morales J. Consequences of nest reuse for parasite burden and female health and condition in blue tits, Cyanistes caeruleus. Anim Behav. 2007;73:805-14.

20. Valkiūnas G, lezhova TA, Bolshakov CV, Kosarev V. Blood parasites of the house sparrow Passer domesticus from northwestern Russia, with remarks on trends of global geographical distribution in this bird. J Nat Hist. 2006:40:1709-18.

21. Palinauskas V, Valkiūnas G, Bolshakov CV, Bensch S. Plasmodium relictum (lineage P-SGS1): effects on experimentally infected passerine birds. Exp Parasitol. 2008;120:372-80.

22. Bukauskaitè D, Žiegytė R, Palinauskas V, lezhova TA, Dimitrov D, Ilgūnas M, Bernotienè R, Markovets MY, Valkiūnas G. Biting midges (Culicoides, Diptera) transmit Haemoproteus parasites of owls: evidence from sporogony and molecular phylogeny. Parasit Vectors. 2015;8:303.

23. Jacob J, Ziswiler V. In: Farner DS, King JR, editors. The uropygial gland. In Avian biology. Vol. VI. New York: Academic; 1982. p. 199-324

24. Shawkey MD, Pillai SR, Hill GE. Chemical warfare? Effects of uropygial oil on feather-degrading bacteria. J Avian Biol. 2003;34:345-9.

25. Ruiz-Rodríguez M, Valdivia E, Soler JJ, Martín-Vivaldi M, Martín-Platero AM, Martínez-Bueno M. Symbiotic bacteria living in the hoopoe's uropygial gland prevent feather degradation. J Exp Biol. 2009;212:3621-6.

26. Møller AP, Czirjak GÁ, Heeb P. Feather micro-organisms and uropygial antimicrobial defences in a colonial passerine bird. Funct Ecol. 2009;23:1097-102.

27. Czirják GÁ, Pap PL, Vágási Cl, Giraudeau M, Mureşan C, Mirleau P, et al, Preen gland removal increases plumage bacterial load but not that of feather-degrading bacteria. Naturwissenschaften. 2013;100:145-51.

28. Fallis AM, Smith SM. Ether extracts from birds and carbon dioxide as attractants for some ornithophilic simuliids. Can J Zool. 1964;42:723-30.

29. Russell CB, Hunter FF. Attraction of Culex pipiens/restuans (Diptera: Culicidae) mosquitoes to bird uropygial gland odors at two elevations in the Niagara region of Ontario. J Med Entomol. 2005;42:301-5.

30. Bidlingmayer WL. How mosquitoes see traps: role of visual responses. J Am Mosq Control Assoc. 1994;10:272-9.

31. Clements AN. Biology of mosquitoes. Vol. 2. Sensory reception and behaviour. UK: CABI Publishing; 1999.

32. Lehane MJ. Biology of blood sucking insects. London: Harper Collins Academic; 1991.

33. Cummins B, Cortez R, Foppa IM, Walbeck J, Hyman JM. A spatial model of mosquito host-seeking behavior. PLoS Comput Biol. 2012;8:e1002500.

34. Takken W, Verhulst NO. Host preferences of blood-feeding mosquitoes. Ann Rev Entomol. 2013:58:433-53.

35. Moyer BR, Rock AN, Clayton DH. Experimental test of the importance of preen oil in rock doves (Columba livia). Auk. 2003;120:490-6.

36. Douglas N, Douglas N, Derrett R. Special interest tourism: context and cases. Australia: John Wiley and Sons; 2001.

37. Lowther JK, Wood DM. Specificity of a black fly, Simulium euryadminiculum Davies, toward its host, the common loon. Can Entomol. 1964:96:911-3.

38. Bennett GF, Fallis AM, Campbell AG. The response of Simulium (Eusimulium) euryadminiculum Davies (Diptera: Simuliidae) to some olfactory and visual stimuli. Can J Zool. 1972;50:793-800

39. Marzal A, Ricklefs RE, Valkiunas G, Albayrak T, Arriero E, Bonneaud C, et al. Diversity, loss, and gain of malaria parasites in a globally invasive bird. PLoS One. 2011;6:e21905.

40. Pap PL, Vágási Cl, Osváth G, Mureşan C, Barta Z. Seasonality in the uropygial gland size and feather mite abundance in house sparrows Passer domesticus: Natural covariation and an experiment. J Avian Biol. 2010:41:653-61.

41. Peig J, Green AJ. New perspectives for estimating body condition from mass/length data: the scaled mass index as an alternative method. Oikos. 2009;118:1883-91.

42. Peig J, Green AJ. The paradigm of body condition: a critical reappraisal of current methods based on mass and length. Funct Ecol. 2010;24:1323-32.

43. Svensson L, Mullarney K, Zetterström D. Guía de Aves: España, Europa y Región Mediterránea. Madrid: Ediciones Omega, S.L; 2009.
44. Bensch S, Stjernman M, Hasselquist D, Ostman O, Hansson B, Westerdahl H, et al. Host specificity in avian blood parasites: a study of Plasmodium and Haemoproteus mitochondrial DNA amplified from birds. Proc Biol Sci. 2000; 267:1583-9.

45. Waldenström J, Bensch S, Hasselquist D, Ostman O. A new nested polymerase chain reaction method very efficient in detecting Plasmodium and Haemoproteus infections from avian blood. J Parasitol. 2004;90:191-4.

46. Sambrook J, Fritsch EF, Maniatis T. Molecular cloning: a laboratory manual. Cold sprin. Vol. 3. New York: Cold Spring Harbor Laboratory; 2002.

47. Galván I, Sanz JJ. Feather mite abundance increases with uropygial gland size and plumage yellowness in Great Tits Parus major. Ibis. 2006;148:687-97.

48. Martín-Vivaldi M, Ruiz-Rodríguez M, José Soler J, Manuel Peralta-Sánchez J, Méndez M, Valdivia E, et al. Seasonal, sexual and developmental differences in hoopoe Upupa epops preen gland morphology and secretions: evidence for a role of bacteria. J Avian Biol. 2009:40:191-205.

49. Moreno-Rueda G. Uropygial gland size, feather holes and moult performance in the House Sparrow Passer domesticus. Int J Avian Sci. 2014;156:457-60.

50. Moreno-Rueda G. Body-mass-dependent trade-off between immune response and uropygial gland size in house sparrows Passer domesticus. J Avian Biol. 2015:46:40-5.

51. Álvarez-Barrientos A, Arroyo J, Canton R, Nombela C, Sanchez-Perez M. Applications of flow cytometry to clinical microbiology. Clin Microbiol Rev. 2000;13:167-95.

52. Nakagawa S, Schielzeth $H$. Repeatability for gaussian and non-gaussian data: a practical guide for biologists. Biol Rev Camb Philos Soc. 2010; 85:935-56.

53. R Development Core Team. R: a language and environment for statistical computing. 2015.

54. SAS. JMP version 10.0. Cary, NC: SAS Institute Inc; 2012

55. Martínez De La Puente J, Rivero-De Aguilar J, Del Cerro S, Argüello A, Merino S. Do secretions from the uropygial gland of birds attract biting midges and black flies? Parasitol Res. 2011;109:1715-8.

56. Clayton DH, Koop JAH, Harbison CW, Moyer BR, Bush SE. How birds combat ectoparasites. Open Ornithol J. 2010;3:41-71.

57. Garcia-Longoria L, Møller AP, Balbontín J, de Lope F, Marzal A. Do malaria parasites manipulate the escape behaviour of their avian hosts? An experimental study. Parasitol Res. 2015;114:4493-501.

58. González CA. Changes in mass of the preen gland in rock ptarmigans (Lagopus muta) in relation to sex, age and parasite burden 2007-2012, MS thesis. Reykjavik: University of Iceland; 2014

59. Moreno-Rueda G. Uropygial gland size correlates with feather holes, body condition and wingbar size in the house sparrow Passer domesticus. J Avian Biol. 2010;41:229-36

60. Dumbacher J, Pruett-Jones S. Avian chemical defenses. In: Nolan Jr V Ketterson ED, editors. Current Ornithology. New Jersey, USA: Plenum Press; 1996. p. 137-4.

61. Piault R, Gasparini J, Bize P, Paulet M, McGraw KJ, Roulin A. Experimental support for the makeup hypothesis in nestling tawny owls (Strix aluco). Behav Ecol. 2008;19:703-9.

62. Pap PL, Adam C, Vágási Cl, Benkő Z, Vincze O. Sex ratio and sexual dimorphism of three lice species with contrasting prevalence parasitizing the house sparrow. J Parasitol. 2013:99:24-30.

63. Verhulst NO, Beijleveld H, Knols B, Takken W, Schraa G, Bouwmeester H, et al. Cultured skin microbiota attracts malaria mosquitoes. Malar J. 2009:8:302.

64. Verhulst NO, Andriessen R, Groenhagen U, Bukovinszkiné Kiss G, Schulz S, Takken W, et al. Differential attraction of malaria mosquitoes to volatile blends produced by human skin bacteria. PLoS One. 2010;5:e15829.

65. Smallegange RC, Verhulst NO, Takken W. Sweaty skin: an invitation to bite? Trends Parasitol. 2011:27:143-8.

66. Syed Z, Leal WS. Acute olfactory response of Culex mosquitoes to a humanand bird-derived attractant. Proc Natl Acad Sci U S A. 2009:106:18803-8.

67. Martín-Vivaldi M, Peña A, Peralta-Sánchez JM, Sánchez L, Ananou S, RuizRodríguez $\mathrm{M}$, et al. Antimicrobial chemicals in hoopoe preen secretions are produced by symbiotic bacteria. Proc R Soc B R Soc. 2010;277:123-30.

68. Jacob J, Eigener U, Hoppe $U$. The structure of preen gland waxes from pelecaniform birds containing 3,7-dimethyloctan-1-ol - An active ingredient against dermatophytes. A J Biosci. 1997;52:114-23.

69. Law-Brown J. Chemical defence in the red billed wood hoopoe Phoeniculus purpureus. MS thesis. South Africa: University of Cape Town, Rondebosch; 2001. 
70. Bandyopadhyay A, Bhattacharyya SP. Influence of fowl uropygial gland and its secretory lipid components on growth of skin surface bacteria of fowl. Indian J Exp Biol. 1996;34:48-52.

71. Baggott GK, Graeme-Cook K. Microbiology of natural incubation. In: Deeming DC, editor. Avian incubation behaviour, environment and evolution. Oxford: Oxford University Press; 2002. p. 179-91.

72. Cook MI, Beissinger SR, Toranzos GA, Rodriguez RA, Arendt WJ. Trans-shell infection by pathogenic micro-organisms reduces the shelf life of nonincubated bird's eggs: a constraint on the onset of incubation? Proc R Soc B Biol Sci. 2003;270:2233-40.

73. Cook MI, Beissinger SR, Toranzos GA, Arendt WJ. Incubation reduces microbial growth on eggshells and the opportunity for trans-shell infection. Ecol Lett. 2005;8:532-7.

74. Bailey RE. The incubation patch of passerine birds. Condor. 1952;54:121-36.

75. Jones RE. The incubation patch of birds. Biol Rev. 1971:46:315-39.

76. Møller AP, Erritzøe J, Rózsa L. Ectoparasites, uropygial glands and hatching success in birds. Oecologia. 2010;163:303-11.

77. Knowles SCL, Wodd MJ, Alves R, Wilkin TA, Bensch S, Sheldon BC. Molecular epidemiology of malaria prevalence and parasitaemia in a wild bird population. Mol Ecol. 2011;20:1062-76.

78. Isaksson C, Sepil I, Baramidze V, Shellsdon BC. Explaining variance of avian malaria infection in the wild: the importance of host density, habitat, individual life-history and oxidative stress. BMC Ecol. 2013;13:15-40.

79. McCurdy DG, Shutler D, Mullie A, Forbes MR. Sex-biased parasitism of avian host: relations to blood parasite taxon and mating system. Oikos. 1998:82:303-12.

80. Jacob S, Immer A, Leclaire S, Parthuisot N, Ducamp C, Espinasse G, et al. Uropygial gland size and composition varies according to experimentally modified microbiome in great tits. BMC Evol Biol. 2014;14:134.

81. Bradley CA, Altizer S. Urbanization and the ecology of wildlife diseases. Trends Ecol Evol. 2007;22:95-102.

82. Hamer SA, Goldberg TL, Kitron UD, Brawn JD, Anderson TK, Loss SR, et al. Wild birds and urban ecology of ticks and tick-borne pathogens, Chicago, Illinois, USA, 2005-2010. Emerg Infect Dis. 2012;18:1589-95.

\section{Submit your next manuscript to BioMed Central and we will help you at every step:}

- We accept pre-submission inquiries

- Our selector tool helps you to find the most relevant journal

- We provide round the clock customer support

- Convenient online submission

- Thorough peer review

- Inclusion in PubMed and all major indexing services

- Maximum visibility for your research

Submit your manuscript at www biomedcentral.com/submit

C Biomed Central 